\section{Investigation of Preservice Preschool Teachers' Views on Environmental Problems and Relevant Suggestions of Solution}

\author{
Yakup Doğana, ${ }^{*}$, Ahmet Simsar ${ }^{b}$
}

$\begin{array}{lr}\text { Received: } & 08 \text { November } 2018 \\ \text { Revised: } \quad 26 \text { December } 2018 \\ \text { Accepted: } \quad 26 \text { December } 2018 \\ \text { ISSN: 1307-9298 } \\ \text { Copyright (C) IEJEE } \\ \text { www.iejee.com }\end{array}$

DOI: 10.26822/iejee.2019248589

\begin{abstract}
This study aimed to investigate preservice preschool teachers' opinions on environmental problems and their suggestions of solution. This study was conducted through case study which is one of the qualitative research design. The study group consisted of 62 senior preservice teachers studying Preschool Teacher Education at a public university in South-eastern Anatolia. Eight semi-structured open-ended questions were asked to preservice teachers as the data collection tool. The data was transferred to the electronic environment and content analysis was made with the NVivo11 program. According to the results, it was observed that the majority of preservice teachers didn't take a course related to the environment during their education, almost half of them didn't participate in any environmental activities, and the most of them did not have membership in any non-governmental organizations related to environment. It was identified that preservice teachers considered global warming as the main global-scale environmental problem, and air, water and soil pollution as other major environmental issues in Turkey. Additionally, the study showed that preservice teachers regarded human factor as the main reason of environmental issues, and that natural environment would be harmed and human life would be challenged as a result of environmental issues. In the solution of environmental issues, the study showed that raising awareness, taking responsibility and receiving education were seen necessary.
\end{abstract}

Keywords: Environmental Problems, Suggestions, Preservice Preschool Teachers, Qualitative Study

\section{Introduction}

Today, many factors such as the rapid population growth, industrialization and reduced natural resources generate various global environmental issues. Those are related to humans' unconscious behaviour against environment and environmental problems. It is, therefore, assumed that the biggest danger of environmental issues is that they are at global scale (Aydın \& Kaya, 2011; Harris, 2012; Yücel \& Morgil, 1998). Researchers consider the air, water and soil pollution, climate change, global warming, depletion of the ozone layer, decreased biodiversity, depletion of natural resources, reduced green areas, loss or disappearance of various species, desertification and erosion as the biggest environmental issues today (Aydın \& Kaya, 2011; Aydoğdu \& Gezer, 2006; Harris, 2012; Tsekos \& Matthopoulos, 2009). In order to solve environmental issues, researchers emphasize the necessity of helping people to raise awareness through environmental trainings to be conducted at schools to protect the environment (Alım, 2014; Atasoy \& Ertürk; 2008; Ünal, Mançuhan \& Sayar, 2001; Teksöz, Şahin \& Ertepınar, 2010; Yücel \& Morgil, 1998). In addition, Erten (2005) also emphasized that activities to be carried out with respect to environmental issues were not the responsibility of the environmentalist NGOs only, but of every individual in the society. The author also stated that the educational institutions would contribute to the development of social consciousness and the development of more environmentally friendly individuals with the responsibilities they would undertake in this regard.

It has been stated that knowledge of environmental issues and their sources will motivate individuals in developing social consciousness for the protection of the environment and more conscious behaviour related to the environment (Erten, 2003). In another study (Erten, 2007), it was emphasized that it is possible to raise environmentally-friendly individuals by including subjects related to the protection of environment in the courses given in schools. It was also stated that gaining awareness about the protection of the environment and positive attitude and value judgments towards the environment could be possible only with the environmental education given in schools (Erten, 2003, 2005; Hungerford, \& Volk, 1990; Otto \& Pensini, 2017; Palmer, 2002; Varela- Candamio, Novo-Corti, \& García-Álvarez, 2018; Yücel \& Morgil, 1998). Şimşekli (2004) emphasized that teachers should be a role model about the environmental issues in order to raise awareness with regards to environmental protection, while Yücel and Morgil (1998) stated that the concept of 'environment' must be taught in all levels of education programs starting from primary education and lasting until university, and that individuals should be educated consciously. However, in a study conducted to identify the environmental sensitivity of university students (Yıldırım, Bacanak \& Özsoy, 2012), it was concluded that the environmental education course taken by preservice teachers did not turn out to be very effective. In another study (Güven \& Aydoğdu, 2012), the extent of awareness of preservice teachers about environmental issues was investigated and preservice teachers were identified to have insufficient level of awareness against environmental issues. From this point of view, it is necessary to emphasize the importance of the content and the way the courses are taught in relation to environmental education. 
Researchers (Kunt \& Geçgel, 2013; Otto \& Pensini, 2017; Uzun \& Sağlam, 2006; Yücel \& Morgil, 1998) state that individuals should be conscious of environmental issues, otherwise individuals with negative or disinterested attitudes towards the environment will be insensitive to environmental issues. In addition, it has been stated that both the society and the individuals have common responsibilities in the emergence and prevention of environmental issues (Yılmaz, Morgil, Aktuğ \& Göbekli, 2002). From this point of view, it is necessary to raise awareness towards the environment both socially and individually, and to bring about individual and social solutions for environmental issues. It is stated that this can only be achieved by raising people's awareness through an effective environmental education, creating a permanent and sensitive behaviour change to take responsibility in the solution of environmental issues (Erten, 2005; Kesicioğlu \& Alisinanoglu, 2009; Kunt ve Geçgel, 2013; Şenyurt, Temel \& Özkahraman, 2011; Yılmaz et al., 2002; Yücel \& Morgil, 1998). It is stated that this awareness can be achieved by the support of schools and the environmentalist NGOs towards individuals for the protection of the environment (Ozaner, 2004; Tanriverdi, 2009). Therefore, it is of great importance that both teachers and students should be supported with respect to environmental education to be given in schools (Erten, 2005 Şenyurt, Temel \& Özkahraman, 2011; Yılmaz et al., 2002)

Compared with countries in the European Union, it has been identified that "no proper environmental education has been given in Turkey, and informing and raising awareness of people about the environment are the most effective solutions to environmental issues" (Yilmaz et al., 2002, p.157). Environmental education in European Union countries is given more space within the education programs whereas recent studies in Turkey carried out on students in primary and secondary education levels in Turkey have revealed that the education system in Turkey gives less space to environmental issues (Arkış, 1992; Doğan, 1993; Kunt \& Geçgel, 2013; Ozaner, 2004; Soran, Morgil Yücel, Atav, \& Işık 2000; Tanriverdi, 2009; Tican, 1996; Yilmaz et al., 2002). It has also been stated that not every environmental education is able to provide individuals with sufficient levels of awareness and positive attitudes against environmental issues (Aydın, Şahin \& Korkmaz, 2013). For this reason, with respect to how education should be conducted, Saraç and Kan (2015) suggest that during environmental education process, educators "must provide children with sufficient information, develop the sense of adoption towards environment, provide sufficient amount of materials, develop incentive actions and embody the results of the implementation and give feedback about the values and judgments related to the environment" (p. 143) with suggestions on how environmental education can be conducted. However, Yücel and Morgil (1998) emphasized that the education to be given about the environmental issues should start with preschool period and should be gradually added to the education programs. As a consequence of such efforts, it is believed that it is possible to raise a more environmentally-friendly generation which is also more conscious towards environmental issues (Kunt \& Geçgel, 2013; Ozaner, 2004; Saraç \& Kan, 2015; Soran et al., 2000; Tanriverdi, 2009: Tican, 1996; Yılmaz et al. 2002). However, in a study examining the environmentalist attitudes of preservice teachers studying at the faculty of education (Aydın et al., 2013), it was found that environmental attitude scores of preservice preschool teachers were lower when compared to preservice science teachers and elementary teachers. This outcome is thought to be due to the fact that preschool teacher education programs have less space the environmental education than others.

In a study by Altunoğlu and Atav (2009), the researchers asserted that people cause the environment to change and deteriorate through their own actions, as a result of which they will face the danger that may arise from such destruction, and they also emphasize that the main reason of environmental problems are people themselves. In similar studies, researchers have expressed that environmental issues are caused by the way people live and their value judgments, and emphasized the importance of environmental education to prevent environmental issues (Çepel, 2003; Daştan, 1999; Gökçe, Kaya, Aktay \& Özden, 2007; Teksöz et.al., 2010; Uzun \& Sağlam, 2007). Based on such views, it can be asserted that schools have a great responsibility for raising awareness and informing individuals about how to solve environmental issues (Yalçınkaya, 2012). Similarly, Demir and Yalçın (2014) have stated in their study that it can be of great help to raise awareness about environmental issues when individuals are given proper education at schools about how to prevent environmental issues, as a result of which they will learn about the natural environment and how to use natural resources in an efficient and balanced way.

However, Demir and Yalçın (2014) have emphasized the necessity of taking actions for environmental issues on the basis of "gradually increasing population growth in the world, the rapid depletion and pollution of natural resources, the spread of industrial and technological diversity, the necessity of increasing and maintaining the measures on environmental issues..." (p.18). In another study, Yılmaz and Arslan (2011) have stated that countries have different responsibilities in protecting the environment, that the state takes more responsibility for environmental issues in developed countries, while this responsibility falls more on people in developing countries. From this point of view, it can be said that there are many responsibilities both for the communities and individuals as well as schools in taking actions for environmental issues. In addition, researchers have emphasized the importance of environmental education which should start with preschool period by emphasizing that raising environmentally-friendly and conscious individuals towards the environment and environmental problems starting from the preschool period and continuing during the primary and secondary education is the most important step (Gülay \& Ekici 2010; Kolomuç \& Açışlı, 2013; Kunt \& Geçgel, 2013; Metin, 2010; Özden, 2008; Șimşekli, 2004, Yücel \& Morgil, 1998). For this reason, study group of preservice preschool teachers who constitute the first and most important stage of the education were included as the participants of this study. That is why, the current study was important for field and society to see what knows of our children's future teachers about environmental problems and solutions. This study could be showing also necessities of early childhood teacher education programs for improving preservice teachers' knowledge about environment. It is therefore, this study aimed to investigation the extent of awareness of preservice preschool teachers studying at a faculty of education in Turkey, where environmental issues have been experienced in a very intensive way. In line with the purpose of the study, the research question is defined as 'What are the views of preservice preschool teachers on environmental problems and their suggestions of solution?'

\section{Method}

\section{Research Design}

Case study method typically combines numbers of data collection technique (Eisenhardt, 1989) and explains and understands the dynamics of a contemporary phenomenon (Çepni, 2009; Yin, 2011). Case study research method was used in this study, which aims to identify the opinions of the preservice preschool teachers on environmental problems and possible solutions, in order to identify the 
individual perceptions and opinions of the participants directly towards environmental issues, as well as to understand and explain the current situations. Case studies generally aimed to explain deeply cases in its real condition (Yıldrım \& Şimşek, 2013). From this perspective, different codes and themes were formed for the answers of preservice preschool teachers' when asked about environmental issues and possible solutions, through which the perceptions and opinions of the participants were tried to be identified.

\section{Study Group}

In the qualitative studies, it is stated that the large sample size does not mean that more information will be collected, and consequently, sampling should be in the form of purposeful sampling and made without any randomization and within this context (Bas \& Akturan, 2008). Based on this, the study group was appointed with the purposeful sampling model and the working was composed of participants based on volunteering. The study group of this study consisted of 62 ( 54 female and 8 male) preservice teachers (PT) who were senior at preschool education program in one of the state universities in the South-eastern Anatolia region.

\section{Data Collection Tool}

With the aim of identifying preservice preschool teachers views on environmental issues and solutions, an interview form with eight semi-structured open-ended questions was prepared. The opinions of the relevant field experts (in the field of environmental education, in the field of science education, in the field of preschool science education and in the field of language education) were taken while creating the interview questions, and the content validity and language validity of the interview questions were provided. As a pilot implementation, the questions in the interview form were administered to five preschool teacher candidates who were not included in the study, and their opinions were recorded and the comprehensibility of the questions was checked. In the interview form, there are two questions about environmental issues in accordance with the purpose of the study, one question about the sources of environmental issues, one question about the results of environmental issues and how to solve environmental issues and the responsibilities of individuals, society and school in this regard. The questions were asked to the preservice preschool teachers and their answers were recorded with a voice recorder.

\section{Data Analysis}

Creswell (2007) has stated that the data transferred to the electronic environment in the data analysis process should be separated into important concepts, sentences and quotations in order to reveal how the participants perceive the relevant phenomena. The answers given by the preservice teachers to the questions were transferred to the electronic environment and content analysis was made with the NVivo11 program. In this study, the answers of the participants to each question were analysed by the paying attention to case study research method. Furthermore, it is emphasized that the data similar to each other should be brought together within the framework of certain codes and themes in order to organize the data in a more understandable manner (Yıldırım \& Şimşek, 2013). From this point of view, important and common expressions taken from preservice teachers were classified, structural and tactile descriptions were collected under different codes, and percentage (\%) and frequency $(f)$ calculations were made. With these percentage and frequency distributions, it was aimed to explain the opinions of preservice preschool teachers about the subject matter in more detail and in depth.

\section{Results}

The demographic information of the participants shows that the majority of preservice preschool teacher are female $(87.1 \%)$ and graduated from Girls' Vocational High Schools (45.2\%), and the rest of them graduated from Anatolian High Schools (27.4\%) and General High Schools (22.6\%). The mothers of the preservice teachers were mostly primary school graduates $(61.3 \%)$ and their fathers were mostly primary school (40.4\%) and high school graduates (29.0\%). Similarly, in terms of occupation, it is seen that the majority of mothers were housewives $(85.5 \%)$ and fathers were mostly self-employed (32.3\%), unemployed (25.8\%) and civil servants (20.9\%). According to the family residence status, it was found that pre-service teachers mostly lived in provinces (69.4\%) and districts (20.9\%).

In addition, the majority of preservice teachers (67.8\%) in the study did not take any environmental courses during their education and almost half of them did not participate in any environmental activities. In Turkey, there are some classes which related with environment and environmental issues from K-12. However, literacy related with environment is nominal in Turkish science textbooks. That is why, student has lower skills toward protecting and understanding environmental skills (Pektas, Altunoglu, \& Eksi, 2013). However, in universities, the environmental education classes were depending on the majors. For example, in the early childhood teacher education program of the preservice teachers who participated in current study offer one environmental classes as a selective class. Even if this class is a selective class, there are some limitations to select that class such as number of students who can take class. In this, they may have chance to learnt what is the environmental issues, how they can be solve, what are the schools, teachers, and children' role. In addition, it was found that the majority of preservice teachers $(88.8 \%)$ did not have any membership in any environmental non-governmental organizations (NGO).

The preservice preschool teachers' views on global-scale environmental problems were analysed with content analysis and the results are shown in Table 1.

Table 1. Preservice Preschool Teachers' Views on Global-Scale Environmental Problems

\begin{tabular}{|c|c|c|c|}
\hline Theme & Codes & $f$ & $\%$ \\
\hline \multirow{15}{*}{$\begin{array}{l}\text { Global-Scale } \\
\text { Environmental } \\
\text { Issues }\end{array}$} & Global warming & 19 & 20.65 \\
\hline & $\begin{array}{l}\text { Air, water and soil } \\
\text { pollution }\end{array}$ & 15 & 16.30 \\
\hline & $\begin{array}{l}\text { Release of chemical } \\
\text { waste into the } \\
\text { environment }\end{array}$ & 8 & 8.70 \\
\hline & $\begin{array}{c}\text { Extinction of animal } \\
\text { species }\end{array}$ & 7 & 7.61 \\
\hline & Environmental pollution & 6 & 6.52 \\
\hline & $\begin{array}{l}\text { Destruction of the ozone } \\
\text { layer }\end{array}$ & 4 & 4.35 \\
\hline & Industrialization & 3 & 3.26 \\
\hline & Noise pollution & 3 & 3.26 \\
\hline & Drought & 3 & 3.26 \\
\hline & Climate changes & 3 & 3.26 \\
\hline & Globalization & 2 & 2.17 \\
\hline & Visual pollution & 1 & 1.09 \\
\hline & Nuclear power plants & 1 & 1.09 \\
\hline & Epidemics & 1 & 1.09 \\
\hline & I don't know & 16 & 17.39 \\
\hline
\end{tabular}


Table 1 shows that the majority of the preservice preschool teachers considered global warming as the major (20.65\%) environmental problem, and very few $(1.09 \%)$ regard epidemics, nuclear power plants and visual pollution as the major issues. In addition, some of the preservice teachers (16.30\%) indicated air, water and soil pollution as the bases of global-scale environmental problem, and some (17.39\%) did not express any opinion on global environmental problems. However, it was identified that preservice teachers also had different opinions about global-scale environmental issues (industrialization, environmental pollution, noise pollution, release of chemical wastes into the nature, etc.). The examples of some preservice teachers' opinions related to global-scale problems are as follows:

PT7: "Disruption of the natural balance of the universe as a result of water and air pollution caused by global problems."

PT18: "Global warming, ozone depletion, extinction of living beings and species."

PT59: "Global warming, environmental pollution, extinction of species."

The results of the content analysis on preschool teachers opinions on environmental problems in Turkey are given in Table 2.

Table 2. Preservice Preschool Teachers' Views on Environmental Issues in Turkey

\begin{tabular}{|c|c|c|c|}
\hline Theme & Codes & $f$ & $\%$ \\
\hline \multirow{15}{*}{$\begin{array}{l}\text { Environmental } \\
\text { Issues in Turkey }\end{array}$} & $\begin{array}{l}\text { Air, water and soil } \\
\text { pollution }\end{array}$ & 37 & 29.84 \\
\hline & $\begin{array}{l}\text { Environmental } \\
\text { pollution }\end{array}$ & 27 & 21.77 \\
\hline & Chemical wastes & 18 & 14.52 \\
\hline & Noise pollution & 15 & 12.10 \\
\hline & $\begin{array}{l}\text { Unplanned } \\
\text { urbanization }\end{array}$ & 7 & 5.65 \\
\hline & Deforestation & 7 & 5.65 \\
\hline & $\begin{array}{l}\text { Lack of } \\
\text { consciousness on } \\
\text { environmental } \\
\text { pollution }\end{array}$ & 4 & 3.23 \\
\hline & Cosmetics & 2 & 5.85 \\
\hline & $\begin{array}{l}\text { Unconscious } \\
\text { consumption }\end{array}$ & 1 & 0.81 \\
\hline & Drought & 1 & 0.81 \\
\hline & Artificial products & 1 & 0.81 \\
\hline & I don't know & 4 & 3.23 \\
\hline & $\begin{array}{l}\text { Nuclear power } \\
\text { plants }\end{array}$ & 1 & 1.09 \\
\hline & Epidemics & 1 & 1.09 \\
\hline & I don't know & 16 & 17.39 \\
\hline
\end{tabular}

According to the data given in Table 2, the majority of preservice preschool teachers surveyed (29.84\%) expressed that the biggest environmental problem in Turkey was air, water and soil pollution. In addition, others (21.77\%) expressed that the biggest environmental problem in Turkey was environmental pollution. Among many different views, one of the preservice teachers $(0.81 \%)$ considered artificial products while the other one $(0.81 \%)$ considered drought as the main source of environmental issues in Turkey. The issues about chemical waste $(14.52 \%)$ and noise pollution $(12.10 \%)$ were also among the attention-taking opinions of other teachers. In addition, very few teachers (3.23\%) were found to have no opinions with regard to environmental problems in Turkey. The examples of some preservice teachers' opinions to environmental problems in Turkey are as follows:

PT16: "Factory waste, food and beverage wastes."

PT18: "False planning, lack of environmental awareness, improper disposal of waste, destruction of existing woodland and recreation areas."

PT25: "Release of heavy metals into water, release of domestic waste, unconsciousness."

The preservice preschool teachers' opinions on the reasons of environmental problems were analysed with content analysis and the results are shown in Table 3.

Table 3. Preservice Preschool Teachers' Views on the Reasons of Environmental Problems

\begin{tabular}{|c|c|c|c|}
\hline Theme & Codes & $f$ & $\%$ \\
\hline \multirow{15}{*}{$\begin{array}{l}\text { Reasons of } \\
\text { Environmental } \\
\text { Issues }\end{array}$} & Humans & 50 & 64.92 \\
\hline & Lack of education & 9 & 11.69 \\
\hline & Industrialization & 4 & 5.19 \\
\hline & $\begin{array}{c}\text { Unconscious use of } \\
\text { natural resources }\end{array}$ & 2 & 2.60 \\
\hline & Chemical wastes & 2 & 2.60 \\
\hline & Administrators & 2 & 2.60 \\
\hline & $\begin{array}{l}\text { Living and non-living } \\
\text { things }\end{array}$ & 1 & 1.30 \\
\hline & $\begin{array}{c}\text { Unplanned } \\
\text { urbanization }\end{array}$ & 1 & 1.30 \\
\hline & $\begin{array}{l}\text { Air, water and soil } \\
\text { pollution }\end{array}$ & 1 & 1.30 \\
\hline & Global warming & 1 & 1.30 \\
\hline & Globalization & 1 & 1.30 \\
\hline & $\begin{array}{c}\text { Hazardous chemical } \\
\text { gases }\end{array}$ & 1 & 1.30 \\
\hline & I don't know & 2 & 2.60 \\
\hline & Epidemics & 1 & 1.09 \\
\hline & I don't know & 16 & 17.39 \\
\hline
\end{tabular}

According to the data in Table 3, the majority of preservice preschool teachers $(64.92 \%)$ who participated in the study stated that the reason of environmental problems was people. However, some of them (11.69\%) stated that lack of education and very few (5.19\%) stated that industrialization was the main reason. Besides this, other opinions of the preservice teachers on the reasons of environmental problems were related to chemical waste, global warming, administrators, unconscious, and use of natural resources. The examples of some preservice teachers' opinions about the reasons of environmental problems are as follows:

PT9: "Unconsciousness of people, misuse of environment, increased human population."

PT14: "Unconsciousness about the environment, inefficient education."

PT24: "Unconscious deeds of humans, failing to pay attention towards the environment."

The preservice preschool teachers' opinions on the possible results of environmental pollution were analysed with content analysis and the results are shown in Table 4.

According to the results in Table 4, the majority of preservice teachers (16.04\%) who participated in the research reported their opinions by saying that "human life will be challenged" and "the natural environment will be damaged" as a result of environmental problems. Other partici- 
pants (14.6\%) stated that "living spaces of living beings will become narrower". In addition, very few of the participants $(2.47 \%)$ stated their opinions as "I don't know".

Table 4. Preservice Preschool Teachers' Views on the Results of Environmental Pollution

\begin{tabular}{|c|c|c|c|}
\hline Theme & Codes & $f$ & $\%$ \\
\hline \multirow{9}{*}{$\begin{array}{c}\text { Results of } \\
\text { Environmental } \\
\text { Pollution }\end{array}$} & $\begin{array}{l}\text { Natural } \\
\text { environment will } \\
\text { be damaged }\end{array}$ & 13 & 16.04 \\
\hline & $\begin{array}{l}\text { Human life will be } \\
\text { challenged }\end{array}$ & 13 & 16.04 \\
\hline & $\begin{array}{l}\text { Living space of } \\
\text { living beings will } \\
\text { become narrower }\end{array}$ & 12 & 14.60 \\
\hline & $\begin{array}{l}\text { Living beings will } \\
\text { become extinct }\end{array}$ & 11 & 14.00 \\
\hline & $\begin{array}{l}\text { Diseases will } \\
\text { appear }\end{array}$ & 11 & 14.00 \\
\hline & $\begin{array}{l}\text { Global warming } \\
\text { will occur }\end{array}$ & 9 & 11.10 \\
\hline & $\begin{array}{l}\text { Environmental } \\
\text { pollution will occur }\end{array}$ & 6 & 7.41 \\
\hline & $\begin{array}{l}\text { Natural resources } \\
\text { will run out }\end{array}$ & 4 & 4.80 \\
\hline & I don't know & 2 & 2.47 \\
\hline
\end{tabular}

The examples of some preservice teachers' opinions on what could be the result of environmental pollution are as follows:

PT8: "Natural balance will deteriorate, oxygen in the air will become contaminated, human health will be greatly damaged."

PT10: "The glaciers will melt, the ozone layer will be depleted some diseases will become widespread, living things will be greatly damaged."

PT20: "Natural resources will be exhausted, humans and other living beings as well as life will be negatively affected and even endangered."

The preservice preschool teachers' opinions about how to solve environmental problems were analysed with content analysis and the results are shown in Table 5.

According to the data in Table 5, the majority of preservice teachers (52.56\%) who participated in the research believe that environmental problems can be solved by "raising people's awareness". In addition, some of the participants (21.79\%) believed that environmental problems could be solved by "educating people about this issue". However, very few of the participants (1.28\%) expressed their ways towards "creating campaigns on the environment", "no solution", and "becoming a producing society rather than a consuming society". In addition, some of the participants $(6,41 \%)$ had no idea how to solve the environmental problems. The examples of some preservice teachers' opinions on how to solve environmental problems are as follows:

PT8: "With the cooperation of organizations and people supporting the environment."

PT14: "Through raising people's awareness, supporting them with adequate level of education, and planned settlements."

PT20: "It can be solved by not ignoring any cases that disrupt the biological balance, and taking actions against them, though they are trivial."

The preservice preschool teachers' opinions about the responsibilities of individuals towards protecting environment were analysed with content analysis and the results are shown in Table 6.
Table 5. Preservice Preschool Teachers' Opinions on How to Solve Environmental Problems

\begin{tabular}{|c|c|c|c|}
\hline Theme & Codes & $f$ & $\%$ \\
\hline \multirow{10}{*}{$\begin{array}{l}\text { Solutions to } \\
\text { Environmental } \\
\text { Issues }\end{array}$} & $\begin{array}{c}\text { Through raising people's } \\
\text { awareness }\end{array}$ & 41 & 52.56 \\
\hline & $\begin{array}{l}\text { Through educating people } \\
\text { about the issue }\end{array}$ & 17 & 21.79 \\
\hline & $\begin{array}{l}\text { Through the work of } \\
\text { administrators on } \\
\text { environmental issues }\end{array}$ & 4 & 5.12 \\
\hline & $\begin{array}{l}\text { Through imposing sanctions } \\
\text { on the environmental issues }\end{array}$ & 3 & 3.84 \\
\hline & $\begin{array}{l}\text { Through establishing chemical } \\
\text { waste depots and establishing } \\
\text { treatment plants }\end{array}$ & 3 & 3.84 \\
\hline & $\begin{array}{l}\text { Through the cooperation of } \\
\text { environmental organizations } \\
\text { and people }\end{array}$ & 2 & 2.56 \\
\hline & $\begin{array}{c}\text { Through creating campaigns } \\
\text { on the environment }\end{array}$ & 1 & 1.28 \\
\hline & No solution & 1 & 1.28 \\
\hline & $\begin{array}{l}\text { Through becoming a } \\
\text { producing society rather than } \\
\text { a consuming society }\end{array}$ & 1 & 1.28 \\
\hline & I don't know & 5 & 6.41 \\
\hline
\end{tabular}

Table 6. Preservice Preschool Teachers' Opinions on the Duties of Individuals in Protecting the Environment

\begin{tabular}{|c|c|c|c|}
\hline Theme & Codes & $f$ & $\%$ \\
\hline \multirow{13}{*}{$\begin{array}{l}\text { Duties of } \\
\text { Individuals in } \\
\text { Protecting the } \\
\text { Environment }\end{array}$} & $\begin{array}{l}\text { Being conscious about } \\
\text { environmental protection }\end{array}$ & 20 & 23.54 \\
\hline & Being responsible individuals & 16 & 18.82 \\
\hline & $\begin{array}{l}\text { Paying attention to } \\
\text { environmental cleaning }\end{array}$ & 13 & 15.29 \\
\hline & $\begin{array}{l}\text { Protecting one's own } \\
\text { environment }\end{array}$ & 8 & 9.41 \\
\hline & $\begin{array}{l}\text { Being sensitive about } \\
\text { environmental protection }\end{array}$ & 7 & 8.24 \\
\hline & $\begin{array}{l}\text { Helping protect the } \\
\text { environment }\end{array}$ & 5 & 5.88 \\
\hline & Planting trees & 3 & 3.53 \\
\hline & $\begin{array}{l}\text { Not harming living beings and } \\
\text { plants }\end{array}$ & 2 & 2.35 \\
\hline & Protecting natural resources & 2 & 2.35 \\
\hline & Developing empathy & 2 & 2.35 \\
\hline & $\begin{array}{l}\text { Receiving training about } \\
\text { environmental protection }\end{array}$ & 1 & 1.18 \\
\hline & Anything can be done & 1 & 1.18 \\
\hline & I don't know & 5 & 5.88 \\
\hline
\end{tabular}

According to the data in Table 6, the majority (23.54\%) of preservice teachers who participated in the study stated an individual's duty as "being conscious about environmental protection", while some of them (18.82\%) expressed their opinions as "being responsible individuals". Very few participants (1.18\%) expressed their views as "anything can be done" and "receiving training on environmental protection". Also, some of the participants (5.88\%) did not express any opinions about this topic. The examples of some preservice teachers' opinions on the duties of individuals in protecting the environment are as follows:

PT2: "Receiving trainings on environmental protection and sharing this knowledge with the others."

PT5: "At first, the individual himself must not harm the environment, and must not let others pollute it." 
PT32: "As conscious individuals, we must first recognize our responsibility for the natural cycle of natural life."

The preservice preschool teachers' opinions about the responsibilities of the schools towards protecting environment were analysed with content analysis and the results are shown in Table 7.

Table 7. Preservice Preschool Teachers' Opinions on the Duties of Schools in Protecting the Environment

\begin{tabular}{cccc}
\hline Theme & Codes & $f$ & $\%$ \\
\hline & Providing education & 30 & 38.46 \\
\cline { 2 - 4 } & $\begin{array}{c}\text { Raising environmentally } \\
\text { friendly individuals }\end{array}$ & 24 & 30.77 \\
\cline { 2 - 4 } & $\begin{array}{c}\text { Being role models for } \\
\text { students }\end{array}$ & 6 & 7.69 \\
\cline { 2 - 4 } $\begin{array}{c}\text { Duties of } \\
\text { Schools in } \\
\text { Environmental } \\
\text { Protection }\end{array}$ & $\begin{array}{c}\text { Carrying out social club } \\
\text { activities about the } \\
\text { environment }\end{array}$ & 5 & 6.42 \\
\cline { 2 - 4 } & $\begin{array}{c}\text { Imposing sanctions for } \\
\text { environmental protection }\end{array}$ & 2 & 2.56 \\
\cline { 2 - 4 } & $\begin{array}{c}\text { Creating environmental } \\
\text { responsibility in children }\end{array}$ & 2 & 2.56 \\
\cline { 2 - 4 } & Creating cleanliness habits & 1 & 1.28 \\
\cline { 2 - 4 } & I don't know & 8 & 10.26 \\
\hline
\end{tabular}

According to the data in Table 7, the majority (38.46\%) of the preservice teachers who participated in the study stated their opinions about the main duty of schools about environmental protection as "creating environmental responsibility in children", while some others (30.77\%) expressed their views towards "raising environmentally friendly individuals". In this respect, very few (1.28\%) of the participants' opinions about the duties of the schools were identified as "creating cleanliness habits". In addition, some of the participants (10.26\%) answered as 'I don't know'. The examples of some preservice teachers' opinions on the duties of schools in protecting the environment are as follows: PT29: "Creating an understanding in children towards the
importance of the environment, and teaching them how to
save."

PT34: "Providing children with necessary training starting from primary school."

PT38: "Awareness-raising activities can be conducted for students."

The preservice preschool teachers' opinions about the responsibilities of the society towards protecting the environment were analysed with content analysis and the results are shown in Table 8

According to the data in Table 8 , the majority $(23.82 \%$ ) of preservice preschool teachers who participated in the study stated their opinions about the duties of the society as "being conscious about the environment". Very few of the participants (1.19\%) stated their opinion as "planting trees". However, some of the participants (15.48\%) did not have any idea about this issue. The examples of some preservice teachers' opinions on the duties of the society in protecting the environment are as follows.

PT13: "Raising awareness of individuals about environmental protection."

PT40: "Increasing the number of non-governmental organizations in the field of environmental protection and continuous activities conducted by such organizations."

PT58: "Raising educated individuals and being conscious."
Table 8. Preservice Preschool Teachers' Opinions on the Duties of the Society in Protecting the Environment

\begin{tabular}{|c|c|c|c|}
\hline Theme & Codes & $f$ & $\%$ \\
\hline \multirow{13}{*}{$\begin{array}{l}\text { Duties of } \\
\text { Individuals in } \\
\text { Protecting the } \\
\text { Environment }\end{array}$} & $\begin{array}{l}\text { Being conscious about the } \\
\text { environment }\end{array}$ & 20 & 23.82 \\
\hline & $\begin{array}{l}\text { Being responsible for the } \\
\text { protection of the environment }\end{array}$ & 10 & 11.90 \\
\hline & Protecting the environment & 8 & 9.53 \\
\hline & $\begin{array}{l}\text { Being informed about how to } \\
\text { protect the environment }\end{array}$ & 5 & 5.95 \\
\hline & $\begin{array}{l}\text { Increasing participation in } \\
\text { environmental organizations }\end{array}$ & 5 & 5.95 \\
\hline & $\begin{array}{l}\text { Imposing sanctions on those } \\
\text { harming the environment }\end{array}$ & 5 & 5.95 \\
\hline & $\begin{array}{l}\text { Fulfilling one's own individual } \\
\text { responsibilities for the } \\
\text { environment }\end{array}$ & 4 & 4.76 \\
\hline & Protecting natural resources & 4 & 4.76 \\
\hline & $\begin{array}{l}\text { Being a role model for } \\
\text { children to protect the } \\
\text { environment }\end{array}$ & 3 & 3.57 \\
\hline & $\begin{array}{l}\text { Being sensitive for } \\
\text { environmental protection }\end{array}$ & 3 & 3.57 \\
\hline & $\begin{array}{l}\text { Being sensitive towards the } \\
\text { environment }\end{array}$ & 3 & 3.57 \\
\hline & Planting trees & 1 & 1.19 \\
\hline & I don't know & 13 & 15.48 \\
\hline
\end{tabular}

\section{Conclusion, Discussion and Suggestions}

This study was carried out according to case study design within the scope of qualitative research methodology in order to reveal preservice preschool teachers' opinions about environmental problems and possible suggestions of solution.

The fact that the biggest feature of environmental issues is that they are at a global basis requires teachers and preservice teachers to be more sensitive to the global environmental problems. As an example of global environmental problems, researchers emphasize the rapid population growth in the world, decreasing natural resources, industrialization and unplanned urbanization (Şenyurt, et al., 2011). In the studies conducted with university students, global warming is observed to be at the first place among global scale environmental problems, air pollution is the second, and then comes the use of natural resources (Altın, Bancanlı, \& Yıldız, 2002; Aydın \& Kaya, 2011; Aydoğdu \& Gezer, 2006; Erol, 2005; Harris, 2012). Similar results were obtained in the current study and it was found that preservice teachers expressed global warming as the biggest global environmental problem and then came air, water and soil pollution. Additionally, in this study, it was identified that preschool teachers considered the release of chemical waste into the nature and the extinction of various animal species as another global environmental problem. Probably, the perspectives of the university students were impact from their social life, using technology, and academic awareness as teacher. Being a conscious person help them to build their teacher characters. In addition, preservice teachers have chance to social acceptability when they have thoughts about environmental problems and being a conscious for environment.

Researchers state that the most effective method for solving the problem of environmental pollution is the trainings to be conducted in this subject matter (Erten, 2005; Kesicioğlu \& Alisinanoğlu, 2009; Ozaner, 2004; Saraç \& Kan, 2015). Given the studies conducted in Turkey and in other European countries on the extent of attention paid to en- 
vironmental education included in the educational systems, researchers have stated that not enough education is given in Turkey with this respect to the environment when compared to the education programs of other European Union countries (Arkış, 1992; Dogan, 1993; Kunt \& Geçgel , 2013; Ozaner, 2004; Yılmaz et al., 2002). As a result of this situation, it is thought that, unless the measures are taken with the education, the global environmental problems will be experienced in different ways in Turkey such as the reduction of natural resources, air, water and soil pollution, and chemical wastes. In this study, preschool teachers were observed to state air, water and soil pollution, environmental pollution, chemical wastes and noise pollution as the biggest environmental problems in Turkey. In the study conducted by Polat and Bahar (2012), problems such as environmental pollution (wastes), air, water and soil pollution are mentioned as major environmental problems which seen in Turkey. In addition, Senyurt et al., (2011), in their study conducted with university students, stated that the majority of students considered environmental pollution and hazardous industrial wastes as the most important environmental problems in their region. Unlike other studies, this study reported that preschool teachers indicated noise pollution as one of the other important environmental problem was seen in Turkey. The reasons of these differences were probably about preservice teachers' majors. For instance, YIlmaz et al. (2002) studied with university students who study in Chemistry. That's why the students mostly stated as perspectives of chemist to environmental problems. However in the current study, preservice early childhood teachers stated their perspectives as a kindergarten teacher which mostly they will be seen in their work noisy.

The fact that environmental problems have become a threat to the natural life and humanity have revealed the vital importance of these problems (Şenyurt et al., 2011). In this case, it is necessary to know what can be the reason of environmental problems in order to solve them. In a study by Altunoğlu and Atav (2009), the researchers have asserted that people cause environmental deterioration and change, and they themselves are faced with the danger as a result of their own activities, and that the main reason of environmental problems is people. In addition, researchers have emphasized that people's lifestyles and value judgments are the main causes of environmental problems, and that individuals' participation in trainings about environmental issues and in environmental activities are of great importance in creating the necessary atmosphere for the solution of environmental problems (Çepel, 2003; Daştan, 1999; Gökçe, Kaya, Aktay \& Özden, 2007; Kunt \& Geçgel, 2013; Ozaner, 2004; Teksöz et.al., 2010; Uzun \& Sağlam, 2007). Similar to the results of previous studies on the reasons of environmental problems, the results of this study showed that preservice teachers considered people as the main reason of environmental problems. Demir and Yalçın (2014), in their study, have stated that the trainings at schools on environmental problems will enable people to know about the natural environment in which an individual reside, learn how to use natural resources efficiently and in a balanced way, which will help raise awareness about environmental problems. It has been emphasized that preservice preschool teachers who will conduct preschool education which is the most basic step of education in this subject, should have environmental sensitivity and show the sensitivity required to raise awareness of students (Yücel \& Morgil, 1998).

In addition, a number of studies in the literature have in dicated that the main reason of environmental problems is people, and thus the most affected group will again be people and other natural areas (Erol \& Gezer, 2006; Taştepe \& Aral, 2014). Genç and Genç (2013) have stated that environmental problems negatively affected both human life and natural balance. In this study, the majority of preservice preschool teachers stated that human life would become harder as a result of environmental pollution, the natural environment would be harmed, the living spaces of the living beings would be narrowed and the diseases would occur. Similarly, Erten (2005) stated that not only human existence would be threatened, but also the world would become uninhabitable as a result of environmental problems.

Attitudes and behaviors or habits of people lie on the basis of environmental problems. Therefore, the attitudes, behaviors and habits of people can help solve the environmental problems if they are made positive by environmental education. Thus, individuals have an important role to get rid of environmental problems (Teksöz et al., 2010; Uzun \& Sağlam, 2007). Erten (2007) has stated that people who are the main actors of environmental problems should be aware of this issue. It is, therefore, obvious that education is important to solve and prevent environmental problems by informing individuals about the environmental issues and creating positive attitudes (Erten, 2005; Saraç \& Kan, 2015; Senyurt et al., 2011). In the current study, it was found that the majority of the participants stated that individuals should be conscious about the solution of environmental problems and that they should be provided with training on the environment and environmental problems. The reason of their perspectives on the solving environment problems by educating people are their major. They believe that probably because of their major's impact on their perspectives as preservice early childhood teachers. Hence, early childhood teachers take several courses and practices for how they can affect a child life by the giving quality education. They also have chances to see child's physical and emotional changes during education. It is therefore, they stated power of education in human life.

In the literature, it has been stated that schools and non-governmental organizations have great responsibilities to train individuals and develop positive attitudes in order to prevent environmental problems and ensure the effective solution. In addition, it was emphasized that the most important duty of schools for prevention of environmental problems is the education of individuals (Aydın, Şahin \& Korkmaz, 2013; Çepel, 2003; Daştan, 1999; Erten, 2003; Şenyurt et al., 2011; Yalçınkaya, 2012; Yılmaz et al., 2002). In a study by Yücel and Morgil (1998), conducted with university students, the researchers have stated that universities should held activities such as symposiums, panels, conferences and congresses, that they should help raise awareness of people and students, and should be in cooperation with the industry. Similarly, in the current study, it was found out that the preservice teachers stated that the greatest duty of schools in protecting the environment should be educating and then raising awareness of individuals. Likewise, Senyurt et al. (2011) stated that higher education institutions should conduct scientific research in the field of environmental protection and prevention of environmental problems and raise academicians who are sensitive to environmental problems.

The scarcity of natural resources and energy resources and increased pollution due to the rapid population growth, urbanization and industrialization are the main environmental problems. Researchers have indicated that the greatest duty of the society is to ensure environmental awareness and that social participation is necessary for the sake of environmental protection (Kunt \& Geçgel, 2013; Şenyurt et al., 2011). Yücel and Morgil (1998) have asserted that the society should be more aware of the environmental problems. However, Kunt and Geçgel (2013) have stated that the legal measures taken by the governments in the solution of the environmental problems that arise in the global level and the knowledge acquired within the family and social environment are not enough. Likewise, in the current study, it was found out that preservice preschool teachers expres- 
sed the necessity of being conscious of the environment as a society and taking responsibility as a society for the protection of the environment.

As a result, the current study aimed to investigate the views of preservice preschool teachers on the environmental issues and how to overcome these problems, and it was found that the opinions of preservice teachers were similar to the results of previous studies on this subject. Based on the results of the study, it is suggested that both theoretical and applied courses related to environmental education must be involved in the curriculum of preschool teaching programs so that preservice preschool teachers, who will educate the future individuals, can be supported in such a way that they could become more sensitive about environmental issues and environmental protection. Especially by the having some course about environment they may have improved their knowledge about global environmental issues, how those can be solved, and roles of schools on these positions. In addition, by the encouraging preservice early childhood teachers to participate NGO's about environment, they may chance to learn what the environmental problems they have seen are and how they can solve these problems, and educate children as conscious people about environmental problems. Having more courses and also practices should be help preservice teachers to improve their knowledge about environment and environmental problems. it is necessary because most of the preservice teachers had lack of knowledge on the reasons and results of environmental problems. Consequently, they had similar solutions for environmental problems. Additionally, both schools and non-governmental organizations should work more and develop the sensitivity of individuals towards environmental problems in order to raise conscious individuals. In order to protect the environment and to prevent problems, more activities should be arranged for environmental education in order to raise environmentally-friendly individuals starting from preschool period.

\section{References}

Alım, M. (2014). The knowledge and attitudes of primary school teaching students towards environment (Sample of Atatürk University). Eastern Geographical Review, 19(31), 23-35.

Altunoğlu, B. D., \& Atav, E. (2009). Ortaöğretim öğrencilerinin çevre risk algısı. Hacettepe Üniversitesi Eğitim Fakültesi Dergisi, 36, 1-11.

Arkış, S. (1992). The effect of water conservation unit integrated into 6th grade junior high school science curriculum (Unpublished Msc. Thesis). METU, Ankara.

Atasoy, E., \& Ertürk, H. (2008). Çevre için eğitim: Ilköğretim öğrencilerinin çevresel tutum ve çevre bilgisi üzerine bir alan araştırması. Erzincan Eğitim Fakültesi Dergisi, 10(1), 105-122.

Aydın, F., \& Kaya, H. (2011). Sosyal bilimler lisesi öğrencilerinin çevre duyarlılıklarının değerlendirilmesi. Marmara Coğrafya Dergisi, 24, 229-257.

Aydın, S. O., Şahin, S., \& Korkmaz, T. (2013). illköğretim fen bilgisi, sınıf ve okul öncesi ögrretmen adaylarının çevresel tutum düzeylerinin belirlenmesi ve karşılaştırılması. Necatibey Eğitim Fakültesi Elektronik Fen ve Matematik Eğitimi Dergisi, 7(2), 248267. doi: 10.12973/nefmed209.

Aydoğdu, M., \& Gezer, K. (Eds.). (2006). Çevre bilimi. (1. Baskı). Ankara: Anı Yayıncılık.
Baş, T., \& Akturan, U. (2008). Nitel araștırma yöntemleri. NVivo 7.0 ile nitel veri analizi. (1. Baskı). Ankara: SeçkinYayıncılık.

Çepel, N. (2003). Ekolojik sorunlar ve çözümleri. (2. Baskı). Ankara: TÜBiTAK Popüler Bilim Kitapları.

Çepni, S. (2005). Araştırma ve proje çalışmalarına giriş. (Genişletilmiş 2.Baskı). Trabzon: Üçyol Yayıncılık

Creswell, J. W. (2007). Qualitative inquiry \& research design: Chosing among five approaches (2nd edition). Thousand Oaks, CA: Sage.

Daştan, H. (1999). Çevre koruma bilinci ve duyarlıı̆̆ının oluşmasında eğitimin yeri ve önemi: Türkiye örneği (Unpublised Msc. Dissertation). Gazi University, Institute of Social Sciences, Ankara.

Demir, E., \& Yalçın, H. (2014). Türkiye'de çevre eğitimi. Türk Bilimsel Derlemeler Dergisi, 7(2), 7-18.

Doğan, M. (1993). The effect of soil conservation unit integrated into 7 th grade junior high school science curriculum (Unpublished Msc. Thesis). METU, Ankara.

Eisenhardt, K. M. (1989). "Building theories from case study research". Academy of management Review, 14(4), 532-550.

Erol, G. H. (2005). Sınıf öğretmenliği ikinci sınıf öğrencilerinin çevre ve çevre sorunlarına yönelik tutumları (Unpublished Msc. Thesis). Pamukkale University, Institute of Social Sciences, Denizli.

Erol, G. H., \& Gezer, K. (2006). Sınıf öğretmenliği öğretmen adaylarına çevreye ve çevre sorunlarına yönelik tutumları. International Journal of Environmental and Science Education, 1(1), 65-77.

Erten, S. (2003). 5. Sınıf öğrencilerinde "çöplerin azaltılması" bilincinin kazandırılmasına yönelik bir öğretim modeli, Hacettepe Üniversitesi Eğitim Fakültesi Dergisi, 25, 94-103.

Erten, S. (2005). Okul öncesi öğretmen adaylarında çevre dostu davranışların araştırılması. Hacettepe Üniversitesi Ĕgitim Fakültesi Dergisi, 28, 91-100.

Erten, S. (2007). Ekosentrik, antroposentrik ve çevreye yönelik antipatik tutum ölçeğinin Türkçeye uyarlama çalışması. Eurasian Journal of Educational Research, 28, 67-74.

Genç, M., \& Genç, T. (2013). Sınıf öğretmenliği öğrencilerinin çevreye yönelik tutumlarının belirlenmesi. Asian Journal of Instruction, 1(1), 9-19.

Gökçe, N., Kaya, E., Aktay, S., \& Özden, M. (2007). İlköğretim öğrencilerinin çevreye yönelik tutumları. ilk ögeretim Online, 6(3), 452-468.

Gülay, H., \& Ekici, G. (2010). MEB okul öncesi eğitim programının çevre eğitimi açısından analizi. Türk Fen Ĕgitimi Dergisi, 7(1), 74-84.

Güven, E., \& Aydoğdu, M. (2012). Çevre sorunlarına yönelik farkındalık ölçeğinin geliştirilmesi ve öğretmen adaylarının farkındalık düzeylerinin belirlenmesi. Öğretmen Eğitimi ve Eğitimcileri Dergisi, 1(2), 185202.

Harris, F. (2012). Global environmental issues (2nd Ed.). Chichester, UK: Wiley-Blackwell. 
Hungerford, H. R., \& Volk, T. L. (1990). Changing learner behavior through environmental education. The Journal of Environmental Education, 21(3), 8-21. doi: 10.1080/00958964.1990.10753743.

Kesicioğlu, O. S., \& Alisinanoğlu, F. (2009). 60-72 Aylık çocukların çevreye karşı tutumlarının çeşitli değişkenler açısından incelenmesi. Ahi Evran Üniversitesi Ĕgitim Fakültesi Dergisi, 10(3), 37-48.

Kolomuç, A., \& Açışlı, S. (2013). Fen bilgisii ve sosyal bilgiler öğretmen adaylarının çevreye karşı tutumlarının karşılaştırılması. The Journal of Academic Social Science Studies. 7(6), 687-696. doi: 10.9761/ JASSS1739.

Kunt, H., \& Geçgel, G. (2013). Öğretmen adaylarının ağaç ve çevreye yönelik tutumlarının incelenmesii. International Periodical for The Languages, Literature and History of Turkish or Turkic. 8(12), 793-807.

Metin, M. (2010). A study on developing a general attitude scale about environmental issues for students in different grade levels. Asia-Pacific Forum on Science Learning and Teaching, 11(2), 1-19.

Otto, S., \& Pensini, P. (2017). Nature-based environmental education of children: Environmental knowledge and connectedness to nature, together, are related to ecological behaviour. Global Environmental Change, 47, 88-94. doi: 10.1016/j.gloenvcha.2017.09.009.

Ozaner, F. S. (2004). Türkiye'de okul dışı çevre eğitimi ne durumda ve neler yapılmalı? V. Ulusal Ekoloji ve Çevre Kongresi, 5-8 Ekim 2004, İstanbul, Türkiye.

Özden, M. (2008). Environmental awareness and attitudes of student teachers. An empirical research. International Research in Geographical and Environmental Education, 17(1), 40-55. doi: 10.2167/irgee227.0.

Palmer, J. A. (2002). Environmental education in the 21st century: Theory, practice, progress and promise. London: Routledge.

Pektas, M., Altunoglu, B. D., \& Eksi, C. (2013). An investigation of environmental literacy concepts in Turkish elementary science textbooks. International Journal of Academic Research Part B, 5(3), 351-356. doi: 10.7813/2075-4124.2013/5-3/B.53.

Polat, G., \& Bahar, M. (2012). Ortaöğretim 9. sınıf öğrencilerinin çevre sorunları hakkında bilişsel yapılarının tespiti. Abant Izzet Baysal Üniversitesi Eğitim Fakültesi Dergisi. 12(2), 97-120.

Saraç, E., \& Kan, A. (2015). Öğretmen adayları için çevre konularına yönelik tutum ölçeği geliştirme geçerlik ve güvenirlik çalışması. Journal of Research in Education and Teaching. 4(2), 142-150.

Şenyurt, A., Temel, A. B., \& Özkahraman, Ş. (2011). Üniversite öğrencilerinin çevresel konulara duyarlılıklarının incelenmesi. SDÜ Sağlık Bilimleri Dergisi, 2(1), 8-15.

Şimşekli Y. (2004). Çevre bilincinin geliştirilmesine yönelik çevre eğitimi etkinliklerine illköğretim okullarının duyarlılığı. Uludağ Üniversitesi Eğitim Fakültesi Dergisi, 17(1), 83-92.

Soran, H., Morgil, F. İ., Yücel, S., Atav, E., \& Işık, S. (2000). Biyoloji öğrencilerinin çevre konularına olan ilgilerinin araştırılması ve kimya öğrencileri ile karşılaştırılması. Hacettepe Üniversitesi Ĕgitim Fakültesi Dergisi, 18, 128-139.
Tanrıverdi, B. (2009). Sürdürülebilir çevre eğitimi açısından ilköğretim programlarının değerlendirilmesi. Egitim ve Bilim Dergisi, 34(151), 89-103.

Taştepe, T., \& Aral, N. (2014). Üniversite öğrencilerinin çevresel bilgi ve tutumlarının incelenmesi. Ĕgitim ve Öğretim Araştırmaları Dergisi, 3(4), 142-153.

Teksöz, G., Şahin, E., \& Ertepınar, H. (2010). Çevre okuryazarlığı, öğretmen adayları ve sürdürülebilir bir gelecek. Hacettepe Üniversitesi Eğitim Fakültesi Dergisi, 39, 307-320.

Tican, S., (1996). The effect of air conservation unit integrated into 8th grade junior high school science curriculum (Unpublished Msc. Thesis). METU, Ankara.

Tsekos, C. A., \& Matthopoulos D. P. (2009). Ethics, science and the environment: the need for a new environmental worldview. International Journal of Environmental Studies, 66(6), 679-687. doi: 10.1080/00207230903028326.

Ünal, S., Mançuhan, E., \& Sayar, A. A. (2001). Çevre: Bilinci, bilgisi ve eğitimi. İstanbul: Marmara Üniversitesi Yayın No: 680.

Uzun, N., \& Sağlam, N. (2006). Orta öğretim öğrencileri için çevresel tutum ölçeği geliştirme ve geçerliliği. Hacettepe Üniversitesi Eğitim Fakültesi Dergisi, 30(30), 240-250.

Uzun, N., \& Sağlam, N. (2007). Ortaöğretim öğrencilerinin çevreye yönelik bilgi ve tutumlarına "Çevre ve Insan" dersi ile gönüllü çevre kuruluşlarının etkisi. Hacettepe Üniversitesi Eğitim Fakültesi Dergisi, 33, 210218.

Varela-Candamio, L., Novo-Corti, I., \& García-Álvarez, M. T. (2018). The importance of environmental education in the determinants of green behavior: A metaanalysis approach. Journal of Cleaner Production, 170, 1565-1578. doi: 10.1016/j.jclepro.2017.09.214.

Yalçınkaya, E., (2012). Illköğretim 6. sınıf öğrencilerinin çevre sorunları farkındalık düzeyleri. Marmara Coğrafya Dergisi, 25, 137-151.

Yıldırım, A., \& Şimşek, H. (2013). Sosyal bilimlerde nitel araştırma yöntemleri. Ankara: Seçkin Yayıncılık.

Yıldırım, C., Bacanak, A., \& Özsoy, S. (2012). Öğretmen adaylarının çevre sorunlarına karşı duyarlııkları. Kastamonu Eğitim Dergisi, 20(1), 121-134.

Yılmaz, A., Morgil, F. i., Aktuğ, P., \& Göbekli, i. (2002). Ortaöğretim ve üniversite öğrencilerinin çevre, çevre kavramları ve sorunları konusundaki bilgileri ve öneriler. Hacettepe Üniversitesi Eğitim Fakültesi Dergisi, 22, 156-162.

Yılmaz, V., \& Arslan, T. (2011). Üniversite öğrencilerinin çevre koruma vaatleri ve çevre dostu tüketim davranışlarının incelenmesi. Anadolu Üniversitesi Sosyal Bilimler Dergisi, 11(3), 1-10.

Yin, R. K. (2011). Applications of case study research , 3rd ed., SAGE Publications Inc., London.

Yücel, S., \& Morgil, F. İ. (1998). Yüksek öğretimde çevre olgusunun araştırılması. Hacettepe Üniversitesi Eğitim Fakültesi Dergisi, 14, 84-91. 